\title{
Abnormal Epithelial Cell
}

National Cancer Institute

\section{Source}

National Cancer Institute. Abnormal Epithelial Cell. NCI Thesaurus. Code C36745.

An epithelial cell that occurs in human disease or in models of human disease. 